\title{
STRATEGI PEMBELAJARAN AL-QURAN PADA LEMBAGA MAJELIS AL-QURRA' WA AL-HUFFAZ PONDOK PESANTREN AS'ADIYAH SENGKANG KABUPATEN WAJO
}

\author{
Abdul Wahid Hasyim \\ Mahasiswa Pascasarjana UIN Alauddin Makassar \\ Email: Wahyd501@gmail.com
}

\begin{abstract}
The main problem of this research is how is the learning strategy of Alquran at Al-Qurra 'wa Al-Huffaz boarding school boarding board of As'adiyah Sengkang Wajo Regency? The subject matter is divided into three sub-problems or research questions are: 1) How to describe the strategy of memorating the Qur'an to the institution of Al-Qurra 'wa Al-Huffaz boarding school boarding As'adiyah Sengkang Wajo Regency ?, 2) How the institution's efforts in improving the learning strategy The Qur'an in the institution of Al-Qurra 'wa Al-Huffaz boarding boarding school As'adiyah Sengkang Wajo Regency This type of research is a qualitative research / field research with research approach used is sociological, theological, pedagogical and psychological approach. The source of research data obtained directly muhafizd, santri and alumni. Further data collection methods used are interview observation, and documentation and tracing of various literature or references. Then the technique of processing and data analysis is done through three stages, namely data reduction, presentation, and conclusion. The results of this research indicate that: 1) the strategy of memorizing the Qur'an in the institution of Al-Qurra 'wa Al-Huffaz boarding boarding school As'adiyah Sengkang Wajo District covers the selection stage, fostering tajwid, standardization of memorization of Qur'an, the pattern of rote settings and maddarasa system fatappulo seddi continuously and stage mappanre temme 2) efforts made by the institution in improving the strategy of memorizing the Qur'an to the institution of Al-Qurra 'wa Al-Huffaz boarding boarding school As'adiyah Sengkang Wajo District includes strengthening of discipline, fostering recitations and fasahah, , gradually building dormitories, holding regular hifdzil qur'an contests as well as the wisdom of pesantren to join the hafizd who have already attended the equation test. The implication of this research is that it is hoped that this research can become one of the academic contribution for all people who want to learn the pattern of strategy of Quranic memorizing effectively and efficiently both in terms of curriculum of tahfidz institution, personal, and for massive dissemination.
\end{abstract}

Keywords: Learning Alqur'an Strategy, Educational Institution.

\section{PENDAHULUAN}

enghafal Alquran adalah salah satu pencapaian tertinggi dalam upaya memahami dan mengamalkannya. Manusia telah diberi potensi untuk dapat menerima pesan-pesan Allah yang tertulis dalam Alquran, melalui akal dan 
hati nurani. Ayat Alquran adalah wahyu yang kebenarannya bersifat mutlak, sehingga akal tidak cukup untuk memikirkannya. Diperlukan ketajaman hati untuk merasakan firman-Nya ${ }^{1}$

Alquran merupakan mukjizat terbesar yang diwariskan Rasulullah saw. bagi kaum muslimin. Bila berbagai umat di belahan timur dan barat merasa bangga dengan tatanan, perundang-undangan dan aturan mereka, maka umat Islam merasa bangga dengan perundang-undangan dan pedoman hidup yang paling agung yakni Alquran. Keberadaan Alquran mempunyai kedudukan yang sentral dalam sistem kehidupan manusia, khususnya bagi kaum muslimin.

Alquran kitab suci Ilahi yang dapat menghidupkan semangat generasi dari bahaya kemusnahan, dari generasi yang kosong rohaninya menjadi generasi yang hidup kembali dengan pancaran sinar Alquran dan menunjukkan pada jalan yang lurus serta membangkitkannya kembali dari lembah kenistaan menjadi umat yang terbaik yang ditampilkan untuk seluruh manusia.

Alquran sebagai kitab suci yang terakhir bagaikan miniatur alam raya yang memuat segala prinsip disiplin ilmu, oleh karena yaitu, setiap muslim mempercayai Alquran mempunyai kewajiban dan tanggung jawab terhadap kitab sucinya itu ${ }^{2}$. Di antara kewajiban dan tanggung jawab itu adalah mempelajari dan mengajarkan Alquran.

Alquran yang mempunyai kedudukan penting bagi kehidupan manusia, karena pengenalan Alquran mutlak diperlukan. Upaya mengenalkan Alquran itu bukan hanya mengetahui dari segi fisik dan aspek sejarah semata, namun yang lebih penting adalah bagaimana umat Islam mampu membaca, menghafal sekaligus memahami serta mengamalkan makna yang terkandung dalam butir-butir ayat demi ayat dari Alquran. ${ }^{3}$ Namun hal yang perlu diperhatikan adalah membaca Alquran tidak sama dengan membaca koran, majalah ataukah buku-buku lain yang merupakan kalam atau perkataan manusia belaka. Membaca Alquran adalah membaca firman-firman Tuhan dan berkomunikasi dengan Tuhan, maka seseorang membaca Alquran seolah-olah berdialog dengan Tuhan, itulah sebabnya ketika seseorang membaca Alquran dianjurkan untuk senantiasa menjaga adab ketika membaca Alquran atau berdialog dengan Tuhan.

Interaksi setiap muslim dengan Alquran menjadi pemandangan tersendiri di setiap ruang dan waktu, mulai dari belajar membaca, menghafal sampai memahaminya dan membawanya dalam setiap langkah. Pemandangan ini, bisa dilihat di sekitar lingkungan dengan beragam etika saat berinteraksi dengan Alquran. Setiap pribadi memiliki cara tersendiri ketika membawanya, membacanya dan memahaminya, tetapi karena Alquran

${ }^{1}$ Aisyah Arsyad Embas, Rekonstruksi Metotologi Tahfizd Alquran (Cet.I; Makassar : Alauddin University Press, 2011), h. 47.

${ }^{2}$ A. Suad. MZ., dan Muhammad Sidiq, Mutiara Alquran, Sorotan Alquran terhadap Berbagai Teknologi Modern (Cet. I; Surabaya: Al-Ikhlas, 1988), h. 55.

${ }^{3}$ Zulfison dan Muharram, Belajar Mudah Membaca Alquran dengan Metode Mandiri (Cet. I; Jakarta: Ciputat Press, 2003), h. 1. 
merupakan kitab yang sangat mulia, seharusnya diperlakukan dengan mulia pula sesuai dengan tuntunan yang ada. Akan tetapi fenomena dewasa ini banyak yang keluar dari aturan yang sebenarnya, di mana mereka meletakkan Alquran sejajar dengan kakinya yang secara nalar hal tersebut tidak wajar sama sekali bahkan bisa dikatakan sebagai penghinaan terhadap kitab suci yang mulia ini. Sering pula dijumpai di kehidupan masyarakat, begitu banyak orang yang berusaha mempelajari terlebih lagi menghafal ayat-ayat Alquran, namun di lain sisi banyak pula ditemukan dari mereka yang tidak menjaga adab-adab ketika membaca Alquran.

\section{PEMBAHASAN}

A. Strategi Pembelajaran Alquran pada Lembaga Majelis Al-Qurra'wa Al-Huffaz pondok Pesantren As'adiyah Sengkang Kabupaten Wajo.

Sebelum melangkah lebih jauh dalam memaparkan strategi penghalafan Alquran Majelis Al-Qurra' wa Al-Huffaz, Pondok Pesantren As'adiyah Sengkang, terlebih dahulu peneliti ingin memaparkan bahwa Pondok Pesantren As'adiyah pusat Sengkang mengadakan pembinaan hafalan Alqur'an yang dikelola secara otonom dan diberikan desentralisasi kepada tiap tiap tempat, lembaga ini terletak di 3 tempat, yaitu Masjid Jami Sengkang yang berdomisili di jalan KH. Muhammad As'ad Kec. Tempe, ${ }^{4}$ dan Masjid Agung. Ummul Qura' Kab. Wajo yang sekarang berpindah lokasi ke Asrama Tahfidzul Qur'an Ummil Hasanah di Lompo Kec. Tempe, ${ }^{5}$ serta Masjid AI-Ikhlas Lapongkoda yang sekarang berpindah ke Masjid Al Burhan Pattirosompe Kec. Tempe. ${ }^{6}$

Penelitian ini akan memaparkan strategi penghalafan Alquran Majelis Al-Qurra' wa Al-Huffaz Pondok Pesantren As'adiyah Sengkang dan perbedaan masing-masing dari ke 3 tempat tersebut dalam membina dan mencetak generasi tahfidz di sengkang Kabupaten Wajo.

Adapun strategi penghalafan Alquran Majelis Al-Qurra' wa Al-Huffaz Pondok Pesantren As'adiyah Sengkang Adalah sebagai berikut:

\section{Tahap Seleksi}

Tahap seleksi untuk masuk dalam pembinaan menghafal di lembaga Majelis $\mathrm{Al}$ Qurra' wa Al-Huffaz Pondok Pesantren As'adiyah Sengkang sangat selektif dan melalui beberapa tahap diantaranya:

a. Tes kelancaran mengaji

b. Tes hafalan

${ }^{4}$ Gurutta Muhammadong Idris (48 tahun) Ketua Majelis Al-Qurra' wa Al-Huffaz As'adiyah Sengkang Kab. Wajo, Wawancara, Sengkang 16 Desember 2017

5 Muhammad Raif (21 tahun) Muhafizd Majelis Al-Qurra' wa Al-Huffaz As'adiyah Ummil Hasanah Sengkang Kab. Wajo, Wawancara, Sengkang 24 Desember 2017

6 Abdul Waris Ahmad (39 tahun) Muhafizd Majelis Al-Qurra' wa Al-Huffaz As'adiyah Pattirosompe Sengkang Kab. Wajo, Wawancara, Sengkang 28 Desember 2017 
Setelah semua calon santri menunggu pengumuman selama 3 hari, maka para calon santri dapat melihat pengumuman yang berdasarkan pertimbangan, musyawarah para muhafizd dan hasil penilaian dari tahap awal, yaitu kelancaran mengaji, ditempel oleh muhafizd di dinding pengumuman Masjid Jami' As'adiyah Sengkang.

Berbeda halnya dengan Majelis Al-Qurra' wa Al-Huffaz Pondok Pesantren As'adiyah (Pattirosompe) Sengkang, di tempat ini tahap seleksi tidak seketat yang ada di Masjid Jami' dan Ummil Hasanah, salah satu Muhafizd disana memberikan informasi kepada peneliti bahwasanya setiap santri yang ingin menghafal di tempat ini tidak dibatasi, baik dari skala kemampuan menghafal, statistik kecerdasan, kelancaran bacaan maupun kemampuan tajwid. Memang secara formal diadakan tes oleh para muhafizd, akan tetapi tes tersebut hanya menjadi formalitas untuk mengetahui sejauh mana kemampuan para calon santri untuk diberikan bimbingan secara proposional. Jadi pada dasarnya setiap santri yang ingin menghafal Alquran dengan Niat (ati macinnong) adalah modal utama untuk menghafal ditempat ini, kalau niat itu sudah ada maka sudah bisa diberikan pembinaan secara bertahap sampai betul betul mahir. ${ }^{7}$ Bahkan walaupun calon santri tersebut belum mahir mengaji (Baru Iqra 4) Pun juga diberikan kesempatan untuk mendapatkan pembinaan ditempat ini. ${ }^{8}$

majeppunna sininna ati macinnonna anana'e iyya maeloe makkafala akorang weddingngi nafalomoi puang Allahu taala narekko engka muakki simata tuli biretteangngi nennia mappatu patukengngi alebbirenna tau makkafala akorangnge nasaba sininna amala'e taggattung'i koritu rinia'e, narekko makessinni nia'na, insya Allah mabbarakkai afala' akoranna, Artinya sesungguhnya hati yang jernih bagi seorang santri yang ingin menghafal Alqur'an menjadi salah satu barometer terpenting untuk memulai hafalan dan bisa lebih mendapatkan kemudahan dengan bimbingan dan motivasi dari para muhafizd sebagai upaya untuk mendapatkan keberkahan menghafal Alquran.

Dari perkataan gurutta tersebut peneliti kemudian mulai memikirkan bahwa memang ternyata lembaga tahfizd yang yang hebat itu bukan lembaga tahfizd yang hanya menerima santri yang cerdas, tapi lembaga tahfizd yang baik adalah lembaga tahfizd yang mampu membuat santrinya menjadi cerdas, baik dari kualitas bacaan maupun kuantitas hafalan. ${ }^{9}$

\section{Pembinaan Tajwid}

Pembinaan tajwid sebelum menghafal Alquran adalah determinasi yang sangat fundamental bahkan suatu hal yang diwajibkan bagi santri untuk mengikuti pembelajaran tajwid secara massif. Pola pembinaan tajwid dilaksanakan di Majelis $\mathrm{Al}$ -

${ }^{7}$ H. Ansar (26 Tahun) Muhafizd Majelis Al-Qurra' wa Al-Huffaz\{ Pondok Pesantren As'adiyah (Pattirosompe) Sengkang, Wawancara, Sengkang 18 Desember 2017.

8 Muhammad Fadli (10 tahun) Santri Majelis Al-Qurra' wa Al-Huffaz\{ Pondok Pesantren As'adiyah (Pattirosompe) Sengkang.

9 Abdul Waris Ahmad (39 tahun) Muhafizd Majelis Al-Qurra' wa Al-Huffaz\{ Pondok Pesantren As'adiyah (Pattirosompe) Sengkang. 
Qurra' wa Al-Huffaz Pondok Pesantren As'adiyah (Masjid Jami) Sengkang dilakukan selama selama 3 bulan, akan tetapi apabila ada santri yang sudah menguasai ilmu tajwid sebelum jangka waktu 3 bulan, maka sudah diperbolehkan oleh Gurutta untuk memulai menghafal Alquran.

\section{Penyeragaman standar Qur'an hafalan}

Ditetapkannya Alquran Menara Kudus sebagai pegangan bagi santri Tahfizd dengan pertimbangan bahwa satu-satunya Alquran yang mudah diperoleh di Sengkang dan dianggap lebih lengkap baik syakalnya maupun tanda-tanda yang lain sekalipun diakui adanya Alquran produk Mekah namun tidak semuda memperolehnya. ${ }^{10} \mathrm{Hal}$ ini ditambahkan oleh salah seorang muhafidz majelis Qurra walhuffazd Ummil hasanah As'adiyah Sengkang, bahwasanya Alquran ini dipilih oleh Gurutta sebagai mushaf hafalan standar, karena mushaf ini merupakan salah satu mushaf yang paling lengkap tanda waqafnya serta halamannya sesuai dengan kalkulasi jumlah halaman per juz yaitu 20 halaman per juz, sehingga dengan memakai jenis Alquran tersebut para santri akan lebih mudah menghafal halaman tiap juz dalam Alquran. ${ }^{11}$

\section{Pola pengaturan hafalan}

a. Hafalan dimulai dari surah As-sajadah dan surah Al-Insan

Bagi santri yang telah dinyatakan lulus bacaan lancar maupun tajwid diperoritaskan terlebih dahulu memulai hafalan dengan surah As-sajadah dan surah al-Insan, sebab masyarakat di Wajo dari sejak A.G.H Muhammad As'ad merintis pendidikan Islam di Sengkang pada tahun 1928 sampai sekarang sudah sangat terbiasa dan sudah menjadi sunnah muaakad diseluruh masjid, baik masjid dikota maupun masjid yang ada dipelosok bahwasanya sujud tilawah yang dilakukan setiap subuh jum'at di perioritaskan membaca Surah As-sajadah di rakaat pertama dan surah Al-Insan dirakaat kedua. Dari kebiasaan masyarakat wajo mendengarkan surah tersebut setiap subuh jum'at telah menjadikan Surah as-sajadah dan surah Al-Insan menjadi budaya secara turun temurun yang digunakan untuk shalat subuh di jumat subuh (Sujud tilawah). ${ }^{12}$

b. Juz 30

Setelah para santri menghafal secara baik surah assajadah dan surah Al-Insan, mereka akan melangkah langsung ke juz 30. Menurut keterangan salah seorang muhafizd Majelis Al-Qurra' wa Al-Huffaz Pondok Pesantren As'adiyah (Masjid Jami') Sengkang bahwasanya hafalan dimulai dari juz 30, karena juz 30 ini

${ }^{10}$ Gurutta Muhammadong Idris (48 tahun) Ketua Majelis Al-Qurra' wa Al-Huffaz\{ As'adiyah Sengkang Kab. Wajo, Wawancara, Sengkang 16 Desember 2017.

${ }^{11}$ Muhammad Raif (21 tahun) Muhafizd Majelis Al-Qurra' wa Al-Huffaz\{ As'adiyah Sengkang Kab. Wajo, Wawancara, Sengkang 24 Desember 2017.

12 Abdul Waris Ahmad (39 tahun) Muhafizd Majelis Al-Qurra'wa Al-Huffaz\{ As'adiyah Pattirosompe Sengkang Kab. Wajo, Wawancara, Sengkang 24 Desember 2017. 
merupakan juz yang paling susah untuk dihafal dan merupakan salah satu tembok penghambat terkuat untuk melanjutkan hafalan ini disebabkan karena juz 30 memuat ayat-ayat pendek di dalamnya serta memiliki halaman terbanyak dibandingkan juz-juz sebelumnya. Alih-alih susahnya juz 30 yang dihafal di periode hafalan tahap awal kemudian saya kembali bertanya gepada Gurutta, bahwa apakah tidak menyusahkan kepada mereka untuk memulai hafalan dari juz yang paling susah?, kemudian Gurutta mengatakan Juz 30 diibaratkan sebagai tembok yang tinggi dimana ketika orang mampu untuk melaluinya maka semua rintanganrintangan yang ada setelahnya akan dilalui dengan mudah. Tentunya sama dengan hafalan Alqur'an apabila dimulai dengan juz yang paling susah untuk dihafal, maka juz- juz selanjutnya akan lebih mudah dihafal sehingga membuat para penghafal Alquran bagaikan menurungi tangga dari puncak gunung. ${ }^{13}$

c. Juz 1

Setelah menghafal Surah Assajadah, Al-Insan dan Juz 30, barulah kemudian para santri memulai hafalan mereka secara berurutan sampai akhirnya di juz 29.

Sebagai target dan capaian minimal kepada para santi untuk estimasi kuantitas bacaan, maka para santri diharapkan mampu menghafal minimal 1 halaman dalam 1 hari dengan pertimbangan bahwa dalam 1 juz terdapat 20 halaman, olehnya itu apabila target tersebut mampu untuk di laksanakan maka dalam 20 hari para santri sudah mampu menghafal Alqur'an 1 juz, serta 10 hari sisanya digunakan untuk murajaah sehingga dalam 1 bulan mereka mampu menghafal Alqur'an minimal 1 juz perbulan. ${ }^{14}$

Adapun di Majelis Al-Qurra' wa Al-Huffaz Pattirosompe Pondok Pesantren As'adiyah Sengkang agak sedikit berbeda, menurut gurutta, bahwa kami tidak terlalu menekankan harus sekian halaman perhari, walaupun kami sangat berharap mereka mampu menghafal dengan kuantitas yang sangat diharapkan, tapi kami khawatir itu sangat mempegaruhi psikologis dan niat santri untuk menghafal Alqur'an, biarkanlah mereka menghafal bukan karena target, tapi murni karena kejernihan hati mendaptkan ridho Allah swt. ${ }^{15}$

\section{Tahap perpindahan juz}

Pola untuk berpindah juz menghafal Alquran dari juz 30, 1,2 dan seterusnya, harus diadakan pengujian oleh muhafizd utama, yaitu Gurutta Muhammadong Idris. Bagi santri yang ingin pindah ke jus selanjutnya terlebih dahulu harus di tes oleh

${ }^{13}$ Gurutta Muhammadong Idris (48 tahun) Ketua Majelis Al-Qurra' wa Al-Huffaz\{ As'adiyah Sengkang Kab. Wajo, Wawancara, Sengkang 16 Desember 2017.

${ }^{14}$ Gurutta Muhammadong Idris (48 tahun) Ketua Majelis Al-Qurra'wa Al-Huffaz\{ As'adiyah Sengkang Kab. Wajo, Wawancara, Sengkang 16 Desember 2017.

15 Abdul Waris Ahmad (39 tahun) Muhafizd Majelis Al-Qurra' wa Al-Huffaz\{ As'adiyah Pattirosompe Sengkang Kab. Wajo, Wawancara, Sengkang 24 Desember 2017. 
Gurutta Muhammadong, pola ini sudah diterapkan puluhan tahun, karena legitimasi hafalan baik untuk berpindah ke juz berikutnya harus mendapatkan pengakuan dari Muhafizd utama yaitu Gurutta muammadong. ${ }^{16}$

Sebagaimana yang yang telah dibahas di awal bahwa santri akan diberikan waktu menghafal Alquran sebanyak $1 \mathrm{Juz}$ selama 30 hari (1 bulan) dengan perincian 1 halaman perhari (20 hari=20 halaman) halaman dan 10 hari sisanya dugunakan untuk murajaah.

a. Maddarasa fatappulo seddi(mengulang bacaan sampai 41 kali)

Hal yang sangat menari dari proses murajaah ini bahwa setiap santri yang ingin pindah juz dan menghadapkan hafalannya ke Gurutta harus mengulangi hafalannya sebanyak 41 kali setiap yang terkenal dengan istilah (Maddarasa fatappulo seddi.

b. Maddarasa pitu fitu

bahkan mulai tahun 2005 ini diperatekkan lagi "Maddarasa pitu-pittl'. Menurut almarhum Gurutta Abdullah Mustafa salah seorang Muhafizd utama , bahwa inilah yang paling menentukan keberhasilan saya, juga sebagai salah satu penyebab keberhasilan rekan santri-santri tahfizd yang lain dalam mempertahankan hafalan Alquran.

c. Maddarasa lima-lima

Semenjak pimpinan Majelis Al-Qurra' wa Al-Huffaz Pondok Pesantren As'adiyah (Masjid Jami') Sengkang berpindah dari Gurutta H. Muhammad Yahya ke Gurutta Muhammadong, darasa lima lima ini diterapkan, karena sejak beliau memegang kendali pimpinan salah satu programnya adalah pembuatan ijazah bagi hafizd yang memiliki hafalan 5 juz ke atas.

\section{Tahap Mappanre temme}

Tahap ini adalah tahap akhir dan juga sebagai rasa syukur bagi santri yang telah menyelesaikan hafalannya 30 juz dan telah mendapatkan gelar Hafizd.

\section{B. Upaya peningkatan strategi Pembelajaran Alquran Majelis Qurra Walhuuffazd As'adiyah Sengkang.}

1. Dalam upaya pembinaan Santri Tahfidz AI-Qur'an As'adiyah, maka dilakukan halhal sebagai berikut:

a. Pembuatan tata tertib

Tata tertib santri Tahfiz Alquran As'adiyah Masjid Jami Sengkang, tata tertib yang harus dipenuhi dalam mengikuti Proses Belajar Mengajar (PBM) Alquran di Masjid Jami' Sengkang. Muhafizd menempelkan aturan dan tata tertib tersebut disetiap asrama dan dinding masjid, bahkan tata tertib tersebut juga termuat disetiap buku saku santri majelis Qurra wa-alhuffazd. Tata tertib ini diharapkan mampu mengarahkan santri untuk lebih menfokuskan diri untuk

\footnotetext{
${ }^{16}$ Muktamir Usman (23 tahun) Muhafizd Majelis Al-Qurra' wa Al-Huffaz\{ As'adiyah Sengkang Kab. Wajo, Wawancara, Sengkang 20 Desember 2017.
} 
menghafal Alquran dan menghindari hal-hal yang dapat mempengaruhi kualitas dan kuantitas hafalan para santri. ${ }^{17}$

b. Pembinaan Tajwid dan tilawah

Pola pembinaan tajwid dan tilawah ini akan bersifat continew karena memang menjadi salah satu program peningkatan mutu di Majelis Al-Qurra' wa AlHuffaz As'adiyah Sengkang, dan program ini dilakukan setiap hari sabtu dari pagi sampai menjelang dhuhur.

c. Memberi Pengajian Pesantren khusus Santri Tahfidz.

d. Mengusahakan sarana prasarana yang memadai

e. Memantapkan pengelolaan pelaksanaan Tahfiz Alquran, termasuk pelaksanaan ujian Tahfidzul Qur'an.

f. Mendirikan Asrama Majelis Al-Qurra' wa Al-Huffaz atau pemondokan khusus. Sejauh ini sudah ada beberapa asrama disertai fasilitas lengkap oleh lembaga demi kelancaran dan kenyamanan para santri, bahkan menurut keterangan dari Gurutta salah seorang Muhafizd bahwa setiap tahun minat dan lonjakan calon santri secara statistik selalu mengalami peningkatan, olehnya itu kalau sekiranya tahun depan kembali mengalami peningkatan, maka kami akan kembali mengkordinasikan kepada ketua PB As'adiyah untuk mengatasi hal tersebut.

g. Mengadakan Lomba Hifdzil Qur'an antar Santri.

Sejak 4 tahun terakhir kami sudah melakukan lomba hifdzil Qur'an dengan ketentuan kelipatan 5 juz. Lomba hafalan 5, 10, 15, 20, 25, dan 30 juz, sebagai motivasi dan sarana murajaah bagi para santri,

h. Sima'an Akbar Alumni dan santri berkolaborasi dan mengadakan acara sima'an tahunan yang diadakan di Mesjid Jami' Sengkang.

i. Mempersiapkan santri siap pakai untuk kegiatan MTQ atau STQ.

j. Mensertifikasi para calon Imam Tarwih setelah melewati masa orientasi Imam.

k. Membuka program Tahfidzul Qur'an di tingkat cabang yang memungkinkan.

1. Mencari pembina bagi para santri

m. Menyusun kurikulum Tahfizul Alquran.

n. Hafidz yang telah menyelesaikan hafalan 30 Juz diperbolehkan mengikuti ujian persamaan di semua tingkatan pendidikan. ${ }^{18}$

Adapun upaya-upaya Yayasan dan PB. As'adiyah untuk meningkatkan mutu dan memenuhi amanah Muktamar As'adiyah XI di Sengkang khusus Majelis Ourra Wal Huffa sebagai berikut:

${ }^{17}$ Andi (24 tahun ) Alumni Majelis Al-Qurra'wa Al-Huffaz\{ Pondok Pesantren As'adiyah (Masjid jami) Sengkang, Wawancara, Sengkang 26 Desember 2017.

18 Pengurus Besar As'diyah, Keputusan Muktamar XIII As'adiyah dan Program Kerja PB. As'adiyah Periode Tahun 2012-2017 (Makassar: De Lamacca, 2013), h. 43. 
2. Dengan upaya-upaya yang telah dilakukan oleh para mudarris dan muhafidz Pengabdian Santri Tahfidz Alqur'an As'adiyah Sengkang

Penulis akan mengemukakan dua hal pokok yang secara nyata dapat diakui sebagai Pengabdian yaitu :

a. Sebagai Imam Tarwih pada tiap Bulan Ramadhan

b. Santri sebagai Peserta Hifdzul Qur'an pada MTQ, STQ, dan Tadarrus AIQur'an tiap tahun, baik di tingkat Kabupaten, Propinsi, Nasional bahkan Internasional. Menurut Drs. H. Abdullah Mustafa Sekretaris Majelis Qurra Wal Huffazd PB As'adiyah Masa Khidmat 2002-2007 bahwa santri-santri yang berprestasi di bidang Hifzil Qur'an khususnya Alumni maupun yang sementara menghafal belum kami inventrisir melalui catatan lengkap, namun yang sempat saya ingat antara lain sebagai berikut :

c. Santri Tahfizd Alquran As'adiyah Sengkang yang berprestasi pada MTQ/STQ dan Tadarrus Alquran.

1. H. Martomo Juara I di tingkat kabupaten, juara 1 di tingkat provinsi di DKI Jakarta 2003, juara 1 tingkat nasional di Palangkaraya, dan juara 3 tingkat Internasional di Makah pada tahun 2003 hafalan 20 Juz. Juara I DKI 2005 Gorontalo Libia 200530 Juz

2. H.lhsan I Juara Pinrang Juara I Juara I Selayar 2003 di Juara I palangkaraya Juara I Gorontalo $20 \mathrm{Juz}$

3. Humaidi Ali Wajo Sul-sel 5 Juz Juara I di NTT, Juz Juara I di Jakarta 10 juz dan Bengkulu 10 Juz Juara I

4. Andi Darussalam Kolaka Sultra 20 Juz Juara I di Parigi Sulteng 30 Juz

5. Amal Hamzah Parigi Sulteng $10 \mathrm{Juz}$,Juara I Bone Sul-sel Gorontalo

6. Arjuna Kolaka Sultra $10 \mathrm{Juz}^{19}$

7. Syamsuddin Wajo Sulteng 30 Juz Juara I, dan Juara I Sultra.

8. Juhaefah Wajo Sultra 20 Juz Juara I

9. Mustari Wajo Sulteng 10 Juz Juara I

10. Sudarmangsyah Wajo Sul-sel 5 Juz Juara 1

11. Ansar, terbaik 2 MTQ Asean di Jakarta.

12. Aman Hamzah 10 juz Saudi Arabiyah juara 2

13. Lukman Saraji, terbaik 1 MTQ Internasional pertama di Cairo, cabang lomba Tilawah.

14. Abdul Rahim Dani, terbaik 1, MTQ Internasional pertama di Cairo, cabang lomba tahfiz\} 3 0 \mathrm { Juz } \text { , dan masih banyak lagi. }

Dengan pencapaian dan berhasilnya strategi pembelajaran yang telah dilakukan pesantren, dan penggunaan pembelajaran di Majelis Al-Qurra'wa Al-Huffaz As'adiyah

${ }^{19}$ Humaidi Ali (32 tahun) Alumni Majelis Al-Qurra' wa Al-Huffaz As'adiyah Sengkang Kab. Wajo, Wawancara, Makassar 16 Desember 2017. 
Sengkang, maka jumlah santri yang telah berhasil pun meningkat dari tahun ke tahun, sehingga kepercayaan masyarakat semakin meningkat pula dengan program tahfidz di pesantren. ${ }^{20}$

\section{PENUTUP}

Gambaran implementasi Strategi pembelajaran Alquran pada lembaga Majelis $\mathrm{Al}$ Qurra' wa Al-Huffaz Pondok Pesantren As'adiyah Sengkang Kabupaten Wajo meliputi tahap seleksi, pembinaan tajwid, penyeragaman standar hafalan Qur'an, pola pengaturan hafalan dan sistem maddarasa fatappulo seddi secara continew serta tahap mappanre temme. Strategi tersebut terbukti sangat efektif, ditandai dengan keadaan santri-santri Tahfiz setiap tahunnya mengalami kemajuan yang datang dari berbagai daerah, baik dalam Kabupaten Wajo maupun di luar Kabupaten se Sulsel bahkan dari luar Propinsi Sul-sel seperti dari Sumatra, Kalimantan, Ambon, Sultra, Sulteng, Sulbar, sampai Malaysia.

${ }^{20}$ Gurutta Muhammadong Idris (48 tahun) Ketua Majelis Al-Qurra' wa Al-Huffaz As'adiyah Sengkang Kab. Wajo, Wawancara, Sengkang 16 Desember 2017. 


\section{DAFTAR PUSTAKA}

Ahmadi Abu. Cara Belajar Yang Mandiri dan Sukses. Solo : Aneka. 1993.

Ash-Shabuni. Muhammad Ali. Ikhtisar Ulumul Qur'an Praktis. trjm. Muhammad

Aziz Abdul al-Rauf al-Hafidh, Kiat Sukses Menjadi Hafizd al-Qur'an, Bandung: Syamil, 2004

Badwilan. Ahmad Salim. Seni Menghafal alquran Cet.I; Solo: Wacana Ilmiah Press, 2008.

Embas. Aisyah Arsyad. Rekonstruksi Metotologi Tahfiz alquran. Cet.I; Makassar : Alauddin University Press, 2011.

Mudhofar Muhlis. 'Strategi Pembelajaran Tahfidzul Qur'an Di Pondok Pesantren Darul Ulum Boyolali". Tesis. Surakarta: Fakultas Manajemen Pendidikan Islam Program Pascasarjana Institut Agama Islam Negeri Surakarta, 2017.

Munjahid. Strategi Menghafal Alquran 10 Bulan Khatam: Kiat-kiat Sukses Menghafal Alquran. Yogyakarta: Idea Press, 2007.

MZ. A. Suad dan Muhammad Sidiq. Mutiara Alquran. Sorotan Alquran terhadap Berbagai Teknologi Modern Cet. I; Surabaya: Al-Ikhlas, 1988.

Nawabuddin Abdurrab. Teknik Menghafal Alquran. Bandung: Al-Gesindo, 1991.

Nur Qadirun. Jakarta; Pustaka Amani. 2001. h.6.Ash-Shabuni. Muhammad Ali. Ikhtisar Ulumul Qur'an Praktis. trjm. Muhammad

Pengurus Besar As'diyah. Keputusan Muktamar XIII As'adiyah dan Program Kerja PB. As'adiyah Periode Tahun 2012-2017. Makassar: De Lamacca, 2013.

Pengurus Besar As'adiyah, Keputusan-keputusan Muktamar As'adiyah tanggal8-10 Oktaber 2002 dan Musyawarah kerja PB AS'adiyah, tanggal, 21-22 Desember 2002. Sengkang Kab. Wajo, t. Penerbit.

Pimp. Pusat As'adiyah Sengkang. Pertumbuhan dan Perkembangan As 'adiyah, 19301980. Sengkang; 1982

Salim Ahmad Badwilan. Panduan Cepat Menghafal Al Quran. Diva Press: Jogjakarta, 2009.

Saprillah, Pengabdian Tanpa Batas: Biografi Anreguruttra Haji Abdul Malik Muhammad, dengan Prolog oleh Nasaruddin Umar. Cet. I; Jawa Tengah: Zadahaniva Publishing, 2014.

Sitti Salmiah Dahlan, Rihla Ilmiah AGH Muhammad As'ad dari Haramain ke Wajo Celebes, dengan pengantar oleh Ahmad Rahman. Cet. I; Jakarta Selatan: Rabbani Press, 2013. 
Walinga Hatta. "Kiyai Haji Muhammad As'ad hidup dan perjuangannya". Skripsi. Makassar: Fakultas Adab IAIN Alauddin Ujung Pandang. 1981.

Yunus Pasanreseng, Sejarah Lahir dan Pertumbuhan Pondok Pesantren As'adiyah Sengkang. Sengkang, Pengurus Besar As'adiyah, 1992.

Zen H.A. Muhaimin. Pedoman Pembinaan Tahfidzul Quran. Jakarta: Pustaka al-Husna, 1983.

Zulfison dan Muharram. Belajar Mudah Membaca Alquran dengan Metode Mandiri Cet. I; Jakarta: Ciputat Press, 2003. 